\section{Plant Morphology}

Mr. H. Hamshaw Thomas's paper entitled "The Old Morphology and the New", read before the Linnean Society on November 10, created considerable interest. In recent years, Mr. Thomas said, a great gulf has arisen between the classical concepts of plant morphology and the new ideas which have been suggested by a study of the modern pteridophytes and of the older Palæozoic floras. A century of botanical investigation has not strengthened the foundations of the old morphology, but its modern exponents on the Continent have been led to regard much of what is termed morphology as irrelevant, and they reject all considerations of phylogeny, as well as the studies on the anatomy and cytology of plants. On the other hand, the foundations of the old system have been seriously shaken. Goethe, in a passage which has been generally overlooked, recognised the validity of some of the considerations of the new morphology, the name applied to the concepts put forward by Lignier, Bower, Tansley, and others. According to this view the body of the higher plants is derived from a thallus with forking branches bearing terminal sporangia; large leaves were derived from branch systems which may or may not have continued to bear sporangia. Thus the reproductive structures of the seed plants are to be considered as modified branches or branch systems rather than as modified foliar structures. The application of these ideas to the flowering plants may lead to considerable changes in our ideas of primitive characters. It is suggested that the flowering plants may be derived from the Palæozoic pteridosperms, and this leads to some new suggestions as to the morphology of modern floral structures.

\section{Science and the Community}

IN an address to the annual conjoint meeting of the Manchester Chemical Societies on November 10, Prof. A. Findlay, under the title "Science and the Community", strongly deprecated extravagant claims advanced as to the part science has to play in the administration of the State. Much disservice has been done to the cause of science by those who fail to recognise that scientific facts are often only one aspect or factor involved in a problem. Science is only one of the great human values, and attempts to antagonise the spirit of science and the quest of beauty, moral values and ethics are a misfortune to the whole community. Prof. Findlay suggested that, so far as industry is concerned, the battle for the recognition of science is already won, but his opinion that science has already received full recognition in the affairs of State was strongly challenged in the subsequent discussion. Prof. Findlay referred to the excessive specialisation of the average graduate in science and emphasised the need for a wider training and for the imparting of general culture and particularly the sense of values which the philosophy of science inculcates. In this, as in his plea for the recognition of the scientific spirit as one of the great expressions of the human spirit, making a contribution to spiritual welfare of mankind fully as important as that of art and literature and religion, Prof. Findlay presented an admirably balanced picture of the position of science in human culture which was greatly appreciated even by those who most strongly criticised either his assumptions as to the position of science in industry and the State, or the intractability of the human factors in social problems to the probings of the scientific mind.

\section{Mexican Archæological Sites}

The Mexican Supreme Court has ruled, according to a Science Service (Washington, D.C.) message from Mexico City, that the country's archæological sites are under the jurisdiction of the Federal Government, and not that of the individual States. This settles an important issue, as has already been indicated in these columns (NATURE, Oct. 29, p. 656). Upheld by the recent decision, Federal Government archæologists arranged to proceed at once to make excavations at Monte Alban, where the spectacular discovery of a treasure tomb was reported last January. The expedition is under the leadership of Alfonso Caso, the discoverer of the Monte Alban tombs, and he will be assisted by a staff of four archæologists and six students. As little appears to have been known in Great Britain of the case upon which the Supreme Court has now pronounced until the matter was sub judice, a brief account of the point at issue and the origin of the dispute between the Federal Government and the States may not be out of place.

HrTheRTo the Federal Government alone, with the exception of the State of Mexico, has shown any interest in the protection and investigation of the antiquities of early Mexican civilisation, the State governments being either indifferent, or without the resources necessary for such an undertaking. When, however, the remarkable treasures discovered in the Monte Alban tombs were placed on exhibition in March last, the enormous intrinsic value of the treasure and the wide-spread interest it aroused, which, it may be said, was responsible for the raising of a considerable sum of money from the public in the form of entrance fees, moved the State of Oaxaca, in which Monte Alban is situated, to lay claim to the treasure and to assert its rights over the antiquities within its borders. This at once raised the whole question of Federal and State jurisdiction in relation to antiquities, upon which the Supreme Court has now given its ruling. The decision has been awaited with anxiety, and there can be no doubt that the ruling is in the best interests of the study of Mexican archæology in present circumstances. The individual States have not the experience or the interest in their antiquities requisite for dealing with questions arising out of the granting of eoncessions for archæological exploration-a matter of importance in view of the widelyextended and invaluable activities of numerous expeditions from the United States now operating in Mexico ; they have neither resources, nor personnel

No. 3290 , Vol. 130] 
for exploration, nor means for the proper display of archæological finds for scientific study as the Federal Government has; while it is generally thought among Mexican archæologists that, had the decision gone in favour of the States, as was expected, they would not have been able to afford their monuments adequate protection from damage, illicit exploitation and other dangers.

\section{The West Indian Hurricane}

THE reports of the hurricane that devastated a large part of Cuba on November 9 after destroying most of the banana crop in Jamaica and causing serious damage and loss of life in Little Cayman and Cayman Brac, show that this was the most destructive of the four storms that have caused much loss of life in the West Indies during the hurricane season that-since it is only once in about ten years that the season extends beyond Octobershould now be ending. The latest estimates give the loss of life in Cuba alone, due mainly to the sea wave on the south coast raised presumably by the southerly hurricane immediately to the east of the storm centre, as more than two thousand. The death roll was therefore much heavier than for the hurricanes which visited the neighbourhood of Galveston on August 13 last, and the Bahamas on September 5, and even for the very violent hurricane of September 26-27 in Puerto Rico. The most recent storm was abnormal in its track as well as in the late date of its occurrence. From information given in the Times of November 11, 12, and 14, it would appear that the centre was moving northwards or a little east of north when it passed to the west of Jamaica, and towards north-east when it crossed Cuba. Many storms pass the neighbourhood of Jamaica or the seas to the south of that island, but they are nearly always moving west or north-west, and, if they recurve to north-east, do so far away and in a much higher latitude. The hurricane season of 1932 will long be remembered, although when the total number of hurricanes in this season can be determined it will probably be found that, in the past fifty years, 1886 and 1887 with eleven storms in each case, still hold first place, while 1916, with a total of eight, remains outstanding in more recent years.

\section{Optical Apparatus at the Science Museum}

A SPECIAL exhibition dealing with optical phenomena and optical instruments will be opened at the Science Museum on November 19, and will remain on view until the middle of February, 1933. A special feature of the exhibition will be a number of demonstrations and experiments operable by visitors. These will illustrate reflection, refraction, dispersion, interference, diffraction, and polarisation of light as well as the working of simple optical instruments such as the telescope and microscope. They should be of particular interest to students, especially to those who have not the facilities for performing such experiments themselves. Other demonstrations will include a large projection microscope designed for the examination of metals in large pieces, a rangefinder specially adapted to take short ranges in the Museum, a home cinematograph projector using standard size film, a large ophthalmoscope for examination of the human eye and a modern epidiascope. The historical development of various optical instruments will be illustrated by examples selected from the Museum collections, and current practice in optical instrument manufacture will be further represented by a selection of modern instruments lent by various firms especially for the exhibition.

\section{Exhibition of British Coastal Craft}

A TEMPORARY exhibition illustrating the fishing boats and coastal craft of Great Britain will be opened in the Entrance Hall of the Science Museum on November 19 and will remain on view until the middle of February, 1933. Some thirty models which have been selected mainly from the large collection of small craft exhibited in Gallery 61 of the Museum, will be shown, in addition to a collection of about sixty photographic transparencies, some of boats for which no models are available in actual use, and others of detailed plans of the more important types. The arrangement will be geographical and will thus show in their proper relations the yoles and sexerns of the Shetlands and Orkneys, the fifies and baldies of the east coast of Scotland, and the cobbles of Yorkshire, together with the eighteenth century herring-busses and the early nineteenth century three-masted luggers which fished in the North Sea. East Anglia will be represented by the distinctive sailing drifters of Yarmouth, the trawlers of Lowestoft and also by the wherries and older keels of the Broads. There will also be the many craft peculiar to the Thames estuary, the barges, lighters and bawleys, besides the older wherries and peter-boats. From the south coast there will be examples of smacks from Ramsgate and Brixham, the eighteenth century hog-boats of Brighton and the luggers which have succeeded them; also the luggers of Penzance and of Fowey. Very little has yet been written about the west coast local shipping, but several typical examples will be included.

\section{Shyok Glaciers and Indus Floods}

UNDER the above title, Mr. J. M. Lacey in an article in the Engineer for October 14 gives an account of the formation of the great ice dams which form across the Upper Shyok River in Kashmir, and of the floods in the Indus valley which result from the release of the large volumes of water pent up behind the dams. The Upper Shyok has its source in the Rima Glacier in the Karakoram region, and in its downward course passes the three important glaciers, Chong Kumdan, 9 miles long, falling 3,000 ft.; the Kichik Kumdan, 7 miles long, falling 3,500 ft. ; and the Aktash, 5 miles long, falling 2,000 ft. In the event of heavy accumulation of snow on the eastern range, these glaciers advance rapidly into the Shyok gorge. On occasions they flow right across the river until they strike the precipitous cliffs on the opposite side, and sometimes turn down the bed

No. 3290, Vol. 130] 